\title{
HUBUNGAN ANTARA KETERAMPILAN BERPIKIR RASIONAL SISWA SMA DENGAN HASIL BELAJAR DALAM PEMBELAJARAN KOOPERATIF MENGGUNAKAN CONSTRUCTIVE FEEDBACK
}

\author{
Rahmi Zulva \\ STKIP PGRI Sumatera Barat Padang, Jl. Gadjah Mada No. 14 A Padang; rahmi.zulva@gmail.com \\ Diterima: 26 Desember 2015. Disetujui: 5 April 2016. Dipublikasikan: April 2016
}

\begin{abstract}
The aim of the study is to examine the connection between rational thinking skills of high school students with the results of cognitive learning in cooperative learning process by providing constructive feedback. In this study used a quasi experimental method to the design of the randomized pretest-posttest control group design. Before doing it, the treatment given is initial tests, and after treatment is given a final test. During the learning process observation occurs. The results showed that the relationship between rational thinking skills of students' cognitive learning outcomes of students after learning at the end of the experimental class there is a significant relationship, with a big increase learning outcomes for 0.551 of great value rational thinking skills. While in the control group there were no correlations.
\end{abstract}

\begin{abstract}
Abstrak: Tujuan dari penelitian ini untuk mengetahui besarnya hubungan antara keterampilan berpikir rasional siswa SMA dengan hasil belajar ranah kognitif dalam proses pembelajaran kooperatif dengan pemberian constructive feedback. Pada penelitian ini digunakan metode quasi eksperimen dengan desain the randomized pretest-posttest control group design. Sebelum melakukan traetment diberi tes awal dan setelah dilakukan treatment diberi tes akhir. Selama proses pembelajran berlangsung dilakukan observasi proses pembelajaran. Hasil penelitian menunjukkan bahwa hubungan antara keterampilan berpikir rasional siswa terhadap hasil belajar ranah kognitif siswa setelah akhir pembelajaran pada kelas eksperimen terdapat hubungan yang signifikan, dengan besarnya peningkatan hasil belajar sebesar 0,551 dari besar nilai keterampilan berpikir rasional. Sedangkan pada kelas kontrol tidak terdapat hubungan.
\end{abstract}

(C) 2016 Pendidikan Fisika FTK IAIN Raden Intan Lampung

Kata kunci: constructive feedback, hasil belajar ranah kognitif, keterampilan berpikir rasional

\section{PENDAHULUAN}

Pembelajaran sains bukan hanya sekedar menguasai sekumpulan pengetahuan yang berupa fakta, konsep, prinsip atau teori saja. Belajar akan lebih bermakna jika peserta didik mengalami apa yang mereka pelajari. Proses pembelajaran sains yang tepat diharapkan dapat membentuk keterampilan maupun kemampuan berpikir dalam menemukan pemecahan secara kritis dan dan rasional berdasarkan permasalahan yang dihadapi dalam kehidupan sehari-hari untuk meningkatkan pemahaman konsep yang dipelajari. (Wibowo, 2012). Oleh karena itu pendidik telah berjuang dengan segala cara mencoba untuk membuat apa yang dipelajari siswa di sekolah agar dapat dipergunakan dalam kehidupan mereka sehari-hari

Proses pembelajaran dewasa ini masih didominasi guru dan tidak memberikan akses bagi anak didik untuk berkembang secara mandiri melalui penemuan dan proses berpikirnya (Trianto,2007). Proses pembelajaran kelas diarahkan pada kemampuan anak untuk menghafal informasi. Otak anak dipaksa 
untuk mengingat konsep dan rumus tanpa dituntut untuk menghubungkannya dengan kehidupan sehari-hari sehingga siswa tidak bisa menarik kesimpulan secara rasional.

Banyak faktor yang mempengaruhi hasil belajar siswa disamping kurangnya variasi proses pembelajaran yang dilakukan guru. Faktor lain yang menyebabkan hasil belajar fisika siswa rendah yaitu kurangnya dilatih keterampilan berpikir rasional siswa sehingga siswa tidak dapat membuat kesimpulan yang tepat dan rasional.

Menurut Suparno (2001), berkembangnya reasoning dan logika terjadi pada tahap pemikiran formal, keterampilan tersebut digunakan dalam memecahkan persoalan yang dihadapi. Secara rasional siswa dapat menganalisis apa-apa yang diamati dan diselesaikan secara benar. Jika keterampilan berpikir rasional siswa dilatihkan dalam pembelajaran, maka diharapkan hasil belajar siswa meningkat.

Banyak model pembelajaran yang dapat digunakan guru untuk bisa melatih keterampilan berpikir rasional siswa, salah satu model pembelajaran yang dapat membantu memfasilitasi dan memudahkan siswa berinteraksi dalam kelas dan mengembangkan keterampilan berpikir rasional serta meningkatkan hasil belajarnya dengan menggunakan model pembelajaran kooperatif.

Pembelajaran kooperatif bukanlah gagasan baru dalam dunia pendidikan. Beberapa penelitian tentang pembelajaran kooperatif menunjukkan hasil yang cukup menggembirakan dalam meningkatkan hasil pembelajaran diantaranya: Al Husni (2010) dalam penelitiannya menggunakan model pembelajaran kooperatif berbantuan web pada materi fluida statis dapat meningkatkan pemahaman konsep dan memfasilitasi kerjasama siswa SMA. Begitu juga Abdul Hakim (2010) dengan penelitiannya yang menggunakan model pembelajaran kooperatif dengan pendekatan problem possing pada topik kesetimbangan benda tegar dapat meningkatkan pemahaman konsep dan keterampilan berpikir kritis siswa SMA.

Menurut hasil penelitian Rahmi (2013) bahwasanya pembelajaran kooperatif disertai dengan pemberian constructive feedback menunjukkan adanya peningkatan hasil belajar ranah kognitif siswa. Dimana pada penelitian tersebut fase-fase tertentu dalam model pembelajaran kooperatif ini dioptimalkan dengan pemberian constructive feedback . Constructive feedback dapat membantu meningkatkan motivasi siswa dalam belajar dan memberikan informasiinformasi untuk perbaikan dan kemajuan siswa. Begitu juga dengan hasil penelitian Rahmi (2014) mengenai pembelajaran kooperatif dengan pemberian constructive Feddback juga dapat meningkatkan keterampilan berpikir rasional siswa.

Berdasarkan latar belakang diatas, maka dapat dilakukan sebuah penelitian untuk mengetahui apakah terdapat hubungan antara hasil belajar ranah kognitif dengan keterampilan berpikir rasional siswa menggunakan pembelajaran kooperatif disertai pemberian constructive feedback.

\section{LANDASAN TEORI}

\section{Model Pembelajaran Kooperatif}

Kooperatif adalah mengerjakan sesuatu secara bersama-sama dengan saling membantu satu sama lainnya sebagai satu tim. Adapun cooperative learning adalah belajar bersama-sama, saling membantu antara satu dengan yang lain dalam belajar dan memastikan bahwa setiap orang dalam kelompok mencapai tujuan atau tugas yang telah ditentukan sebelumnya. Dengan demikian dapat dipahami bahwa cooperative learning menyangkut teknik pengelompokan yang di dalamnya siswa bekerja terarah pada tujuan belajar bersama dalam kelompok kecil yang umumnya terdiri dari 4-5 orang (Trianto, 2007). 
Slavin (2009), mengatakan Cooperative learning adalah suatu model pembelajaran dimana siswa belajar dan bekerja dalam kelompok-kelompok kecil secara kolaboratif yang anggotanya terdiri dari empat sampai enam orang, dengan struktur kelompoknya yang bersifat heterogen. Selanjutnya dikatakan pula keberhasilan belajar dari kelompok tergantung pada kemampuan dan aktivitas anggota kelompok, baik secara individual, maupun secara kelompok.

Johnson \& Johnson (1993) dalam Lie (2007) mengemukakan nilai-nilai yang melekat pada pembelajaran kooperatif, yaitu: saling ketergantungan positif, tanggung jawab individual, interaksi personal, keahlian bekerja sama, dan evaluasi proses kelompok. Model pembelajaran kooperatif tidak sama dengan sekedar belajar dalam kelompok. Pelaksanaan prosedur model kooperatif dengan benar akan memungkinkan pendidik mengelola kelas dengan lebih benar (Lie, 2007).

Model pembelajaran kooperatif ini merupakan model pembelajaran yang membagi siswanya kedalam kelompok kecil, dimana tiap siswa dalam kelompok memiliki kemampuan yang beragam. Hal ini dimaksudkan agar siswa dapat saling bekerja sama dan bertanggung jawab dalam memecahkan permasalahan yang disuguhkan oleh guru.

Terdapat enam langkah utama dalam pembelajaran dengan menggunakan model pembelajaran kooperatif. Langkah-langkah ini ditunjukan pada tabel 1,

Tabel 1. Langkah- Langkah pembelajaran kooperatif

\begin{tabular}{|c|c|c|}
\hline No & Fase & Perilaku Guru \\
\hline 1 & $\begin{array}{c}\text { Fase 1: } \\
\text { Mengklarifikasikan tujuan } \\
\text { dan memotivasi siswa }\end{array}$ & $\begin{array}{l}\text { Guru menjelaskan tujuan } \\
\text { pembelajaran dan } \\
\text { memotivasi siswa }\end{array}$ \\
\hline 2 & $\begin{array}{c}\text { Fase 2: Mempresentasikan } \\
\text { informasi }\end{array}$ & $\begin{array}{c}\text { Guru memberikan } \\
\text { informasi kepada siswa } \\
\text { secara verbal atau dengan } \\
\text { teks }\end{array}$ \\
\hline 3 & $\begin{array}{c}\text { Fase 3: } \\
\text { Mengorganisasikan siswa }\end{array}$ & $\begin{array}{l}\text { Guru menjelaskan kepada } \\
\text { siswa tatacara membentuk }\end{array}$ \\
\hline
\end{tabular}

\begin{tabular}{|c|c|c|}
\hline & ke dalam tim belajar & $\begin{array}{c}\text { tim-tim belajar dan } \\
\text { membantu kelompok untuk } \\
\text { melakukan transisi yang } \\
\text { efisien }\end{array}$ \\
\hline 4 & $\begin{array}{l}\text { Fase 4: Membantu siswa } \\
\text { dalam kerja kelompok }\end{array}$ & $\begin{array}{l}\text { Guru membantu tim-tim } \\
\text { belajar selama mereka } \\
\text { mengerjakan tugasnya }\end{array}$ \\
\hline 5 & Fase 5: evaluasi & $\begin{array}{c}\text { Guru menguji kemampuan } \\
\text { siswa tentang materi atau } \\
\text { kelompok } \\
\text { mempresentasikan hasil } \\
\text { belajarnya }\end{array}$ \\
\hline 6 & Memberikan penghargaan & $\begin{array}{c}\text { Guru mencari cara untuk } \\
\text { mengakui usaha dan } \\
\text { prestasi individual maupun } \\
\text { kelompok }\end{array}$ \\
\hline
\end{tabular}

\section{Constructive Feedback}

Feedback (umpan balik) merupakan suatu bagian penting dalam kegiatan belajar dan pembelajaran. Umpan balik sangat mempengaruhi motivasi belajar siswa. Menurut Slameto (1999) feedback adalah memberi tahu siswa mengenai hasil mereka dalam suatu test/tugas yang mereka kerjakan setelah menyelesaikan suatu proses belajar. Hal ini sejalan dengan pendapat Joyce (1980) yang menyatakan bahwa "Feedback is communicating to a person or group about how their behavior has affected us or other people". Umpan balik merupakan bentuk komunikasi yang terjadi antara 2 pihak yang saling memiliki pengaruh.

Salah satu fungsi dari feedback ialah untuk membuat orang menyadari bahwa sikapnya dapat memberikan dampak terhadap orang lain. Menurut Slameto (1999) feedback memiliki beberapa fungsi yaitu:

1. Fungsi peringatan (harap berhatihati, tujuan pengajaran belum tercapai).

2. Fungsi perbaikan strategi belajar mengajar.

3. Fungsi pengajuan hipotesis (untuk menguji hipotesis mengenai interaksi antara seorang siswa dengan suatu lingkungan belajar). 
4. Fungsi komunikatif (alat pengukur efektivitas komunikasi yang sehat antar manusia).

5. Fungsi psikologis berupa fungsi informasional dan fungsi motivasional.

Maka dapat dilihat bahwa feedback memiliki banyak fungsi. Fungsi feedback dapat sebagai peringatan, perbaikan, pengajuan hipotesis, alat komunikasi, informasi, dan motivasi

Feedback dapat berbentuk constructive atau destructive, tergantung pada kebutuhan si penerima umpan balik atau kebutuhan si pemberi umpan balik. Constructive feedback adalah suatu umpan balik yang memberikan hal-hal yang perlu terhadap perkembangan seseorang atau banyak orang. Constructive feedback sangat efektif apabila digunakan dalam komunikasi interpersonal (Joyce, 1980). Adapun pemberian umpan balik yang membangun (constructive feedback) bertujuan untuk memberi informasi yang akan memberikan perbaikan /kemajuan terhadap peserta didik dan akan membuat hasil yang lebih bagus. Umpan balik yang membangun (constructive feedback) ini ada 2, yaitu:

a. Positive feedback, yaitu informasi atau masukan untuk seseorang mengenai suatu usaha yang telah dilakukannya yang tujuannya untuk memberikan perbaikan.

b. Negative feedback, yaitu informasi untuk seseorang tentang usaha yang perlu ditingkatkan dengan kalimatkalimat negatif, sehingga seseorang mengalami kemunduran dalam kinerjanya.

Banyak siswa yang terkadang tidak memperoleh manfaat dari pemberian feedback. Joyce (1980) menjelskan 6 syarat feedback yang akan memberikan manfaat untuk orang lain, yaitu:
1. Menggambarkan apa yang dilakukan daripada memberi nilai

2. Memberikan informasi khusus, bukan umum.

3. Diberikan secara langsung, dan dapat digunakan untuk perbaikan

4. Diberikan pada waktu yang tepat.

5. Tidak terpaksa dan lebih baik meminta saran.

6. Membuat komunikasi menjadi lancar.

Feedback yang baik menggambarkan apa yang dia lakukan, lebih khusus, langsung, tidak bersifat menjatuhkan si penerima feedback, dan menggunakan komunikasi yang jelas.

\section{Hasil Belajar Ranah Kognitif}

Hasil belajar adalah sesuatu yang diperoleh setelah melakukan kegiatan belajar dan menjadi indikator keberhasilan siswa dalam mengikuti pembelajaran. Hasil belajar ditandai dengan adanya suatu perubahan yang terjadi di dalam diri siswa.

Hasil belajar dapat berupa keterampilan, nilai dan sikap setelah siswa tersebut mengalami proses belajar. Diharapkan hasil belajar dicapai mempunyai efek yang bagus terhadap peningkatan hasil belajar dan minat siswa untuk belajar. Hasil belajar itu dapat diperoleh dengan mengadakan evaluasi atau penilaian hasil belajar, dimana evaluasi tersebut merupakan bagian dari proses belajar. Arikunto, S (2006) menyatakan bahwa :“ Tujuan penilaian hasil belajar adalah untuk mengetahui apakah materi yang diajarkan sudah dipahami oleh siswa dan penggunaan metoda sudah tepat atau belum".

Hasil belajar ini dibagi menjadi tiga bagian, yaitu ranah kognitif, ranah afektif dan ranah psikomotor. Pada penelitian ini, hasil belajar yang diambil yaitu hasil belajar pada ranah kognitif. Hasil belajar ranah kognitif meliputi kemampuan yang menyatakan kembali konsep atau prinsip 
yang telah dipelajari dan kemampuan intelektual. Indikator hasil belajar ranah kognitif ini dihubungkan dengan tingkat berfikir domain kognitif Bloom dalam Anderson dkk (2011) terdiri dari enam tingkat dengan aspek belajar yang berbeda-beda, yaitu:

1. Aspek Mengingat

Berhubungan dengan kemampuan mengenal atau mengingat (recall) berbagai informasi yang telah diterima sebelumnya.

2. Aspek Memahami

Mengkonstruksi makna dari pesan-pesan pembelajaran, baik yang bersifat lisan, tulisan ataupun grafis, yang disampaikan melalui pengajaran, buku atau layar komputer

3. Aspek Mengaplikasikan

Melibatkan penggunaan prosedurprosedur tertentu untuk mengerjakan soal latihan atau menyelesaikan masalah.

4. Aspek Menganalisis Melibatkan proses memecah-mecah materi menjadi bagian-bagian kecil dan menentukan bagaimana hubungan antar bagian dan struktur keseluruhannya.

5. Aspek Mengevaluasi Membuat keputusan berdasarkan kriteria dan standar. Kriteria-kriteria yang paling sering digunakan adalah kualitas, efektivitas, efisiensi dan konsistensi. Kriteria-kriteria ini ditentukan oleh siswa.

6. Aspek Mencipta Berhubungan dengan kemampuan menggabungkan unsur-unsur secara bersamaan untuk membentuk suatu hubungan yang fungsional dan mengorganisasi kembali bagian-bagian kedalam struktur yang baru (Anderson dan Krathwohl, 2011)

\section{Keterampilan Berpikir Rasional}

Berpikir umumnya didefenisikan sebagai proses kognitif atau kegiatan mental yang dapat menghasilkan pengetahuan. Dalam proses berpikir terjadi penggabungan antara persepsi dan unsur-unsur yang ada dalam pikiran. Menurut Poejiadi (dalam Ismienar, dkk, 2009) berpikir dapat dikatakan sebagai bentuk akal yang khas dan terarah, pengetahuan yang diterima melalui indera diproses untuk mencapai kebenaran. Solso (dalam Ismienar, dkk, 2009) berpikir adalah sebuah proses dimana representasi mental baru dibentuk melalui transformasi informasi dengan interaksi yang komplek atribut-atribut mental seperti penilaian, abstraksi, logika, imajinasi dan pemecahan masalah. Dari pengertian tersebut tampak bahwa ada tiga pandangan dasar berpikir, yaitu (1) berpikir adalah kognitif, yaitu timbul secara internal dalam pikiran tetapi dapat diperkirakan dari perilaku, (2) berpikir merupakan sebuah proses yang melibatkan beberapa manipulasi pengetahuan dalam sistem kognitif, dan (3) berpikir diarahkan dan menghasilkan perilaku yang memecahkan masalah atau diarahkan pada solusi.

Dalam penelitian ini, berpikir yang menjadi sasaran/kajian penelitian ialah berpikir rasional yang dikemukakan oleh Novak (1979). Dalam kamus besar bahasa Indonesia, rasional diartikan sebagai pikiran dan timbangan yang logis menurut pikiran yang sehat dan cocok dengan akal. Menurut Novak (1979, dalam Baskoro, 2001) berpikir rasional merupakan sekumpulan aktifitas mental mulai dari yang sederhana menuju yang kompleks, meliputi 10 kecakapan, yaitu: kecakapan siswa dalam menghafal (recalling), meramalkan (imagining), mengklasifikasi (classifying), menggeneralisasi (generalizing), membandingkan (comparing), mengevaluasi (evaluating), menganalisis (analyzing), mensintesis 
(synthesizing), mendeduksi (deducing) dan menyimpulkan (inferring).

5. Keterkaitan Sintaks Pembelajaran Kooperatif dengan Pemberian Constructive Feedback, Hasil Belajar Ranah Kognitif dan Keterampilan Berpikir Rasional

Adapun hubungan antara sintaks pembelajaran kooperatif diberi constructive feedback dengan hasil belajar ranah kognitif dan keterampilan rasional yang diharapkan tergali dalam penelitian ini diperlihatkan dalam Tabel 2.

Tabel 2. Hubungan Sintaks Pembelajaran Kooperatif dengan Pemberian Constructive Feedback, Hasil Belajar Ranah kognitif dan Keterampilan Berpikir Rasional

\begin{tabular}{|c|c|c|}
\hline $\begin{array}{c}\text { Sintaks } \\
\text { Pembelajaran } \\
\text { Kooperatif dengan } \\
\text { Pemberian } \\
\text { Constructive } \\
\text { Feedback } \\
\end{array}$ & $\begin{array}{c}\text { Hasil Belajar } \\
\text { Ranah Kognitif }\end{array}$ & $\begin{array}{c}\text { Keterampilan } \\
\text { Berpikir } \\
\text { Rasional }\end{array}$ \\
\hline $\begin{array}{l}\text { Fase 1: } \\
\text { - } \quad \text { Menyampaik } \\
\text { an tujuan } \\
\text { pembelajaran } \\
\text { - Melakukan } \\
\text { apersepsi } \\
\text { dengan } \\
\text { memberikan } \\
\text { beberapa } \\
\text { pertanyaan } \\
\text { yang disertai } \\
\text { dengan } \\
\text { pemberian } \\
\text { constructive } \\
\text { feedback }\end{array}$ & $\begin{array}{l}\text { Mengingat (C1) } \\
\text { Memahami (C2) }\end{array}$ & - \\
\hline
\end{tabular}

Fase 2:

Menyajikan informasi dan mengemukakan beberapa pertanyaan kepada Mengingat (C1) menggenerali siswa dengan memberikan constructive feedback Memahami (C2) sasikan kelompok belajar

Fase 4:

Membimbing

kelompok belajar

siswa

Fase 5:

Mempersilahkan

salah satu

kelompok

mempresentasikan

hasil diskusinya

dan guru

memberikan

beberapa

pertanyaan kepada

siswa dengan diberi

constructive

feedback

Memahami (C2)

Aplikasi (C3)

Analisis (C4)

Membanding kan

Menggeneral

isasikan

menganalisis

Fase 6:

Memberikan

penghargaan

\section{METODE PENELITIAN}

Metode yang digunakan dalam penelitian ini adalah metode kuasi eksperimen (Quasi experiment), untuk mengetahui hubungan antara keterampilan berpikir rasional dengan hasil belajar ranah kognitif. Desain penelitian yang digunakan dalam penelitian ini ialah "the randomized pretest-posttest control group design.

Dengan menggunakan desain ini subyek penelitian dibagi dalam dua kelompok, satu kelompok sebagai kelompok eksperimen dan satu kelompok lagi sebagai kelompok kontrol, dimana penentuan kelas kontrol dan kelas eksperimen dilakukan secara acak perkelas. Kelompok eksperimen adalah kelompok yang mendapatkan pembelajaran dengan model pembelajaran kooperatif dengan pemberian constructive feedback, sedangkan kelompok kontrol adalah kelompok yang mendapatkan model pembelajaran kooperatif tanpa pemberian constructive feedback.

Fase 3:

Mengorganisasikan siswa kedalam kelompok- 


\section{HASIL DAN PEMBAHASAN}

Untuk melihat hubungan antara hasil belajar ranah kognitif dengan keterampilan berpikir rasional dilakukan uji korelasi. Hasil uji korelasi dapat dilihat pada tabel 3 dan 4 .

Tabel 3. Korelasi Skor Tes Akhir Hasil Belajar Ranah Kognitif dan Keterampilan Berpikir Rasional Kelas Eksperimen

\begin{tabular}{lcccc}
\hline Variabel & $\begin{array}{c}\text { Koefisien } \\
\text { Korelasi }\end{array}$ & $\begin{array}{c}\text { Sig-1 } \\
\text { tailed }\end{array}$ & $\begin{array}{c}\text { Kriteria } \\
\text { taraf } \\
\text { signifikan }\end{array}$ & $\begin{array}{c}\text { Kesimp } \\
\text { ulan }\end{array}$ \\
\hline $\begin{array}{l}\text { Keterampilan } \\
\text { Berpikir }\end{array}$ & 0,361 & 0,023 & 0,05 & $\begin{array}{c}\text { Terdapat } \\
\text { korelasi } \\
\text { yang } \\
\text { Rasional } \\
\text { dengan Hasil }\end{array}$ \\
$\begin{array}{l}\text { Belajar } \\
\text { Ranah }\end{array}$ & & & & \\
Kognitif & & & & \\
\end{tabular}

Tabel 4. Korelasi Skor Tes Akhir Hasil Belajar Ranah Kognitif dan Keterampilan Berpikir Rasional Kelas Kontrol

\begin{tabular}{lcccc}
\hline Variabel & $\begin{array}{c}\text { Koefis } \\
\text { ien } \\
\text { Korel } \\
\text { asi }\end{array}$ & $\begin{array}{c}\text { Sig-1 } \\
\text { tailed }\end{array}$ & $\begin{array}{c}\text { Krite } \\
\text { ria } \\
\text { taraf } \\
\text { signifi } \\
\text { kan }\end{array}$ & $\begin{array}{c}\text { Kesimp } \\
\text { ulan }\end{array}$ \\
\hline Keterampi & 0,214 & 0,106 & 0,05 & $\begin{array}{c}\text { Tidak } \\
\text { terdapat }\end{array}$ \\
lan & & & & Korelasi \\
Berpikir & & & & \\
Rasional & & & & \\
dengan & & & & \\
Hasil & & & & \\
Belajar & & & & \\
Ranah & & & & \\
Kognitif & & & & \\
\hline
\end{tabular}

Berdasarkan Tabel 3 dan 4 diatas terlihat bahwa pada kelas eksperimen terdapat korelasi atau hubungan antara variabel. Untuk melihat persamaan regresi kedua variabel pada kelas eksperimen dapat dilihat pada Tabel 5.
Tabel 5. Nilai Koefisien Korelasi, koefisien Determinasi dan Persamaan Regresi Keterampilan Berpikir Rasional dengan Hasil Belajar Ranah Kognitif Kelas Eksperimen

\begin{tabular}{lccc}
\hline Variabel & $\begin{array}{c}\text { Koefisien } \\
\text { Korelasi }\end{array}$ & $\begin{array}{c}\text { Koefisien } \\
\text { Determin } \\
\text { asi }\end{array}$ & $\begin{array}{c}\text { Persamaan } \\
\text { Regresi }\end{array}$ \\
\hline Keterampi & 0,361 & 0,131 & Y=8,681 \\
lan & & & $+0,551 \mathrm{X}$ \\
Berpikir & & & \\
Rasional & & & \\
(X) & & & \\
dengan & & & \\
Hasil & & & \\
Belajar & & & \\
Ranah & & & \\
Kognitif & & & \\
(Y) & & & \\
\hline
\end{tabular}

Hasil uji regresi tes keterampilan berpikir rasional dengan tes hasil belajar ranah kognitif pada kelas eksperimen diperoleh persamaan regresi $\mathrm{Y}=8,681+0,551 \mathrm{X}$. Artinya peningkatan hasil belajar sebesar 0,551 dari besar nilai keterampilan berpikir rasional

Berdasarkan hasil analisis korelasi keterampilan berpikir rasional (X) dengan hasil belajar ranah kognitif (Y) pada kelas kontrol dan kelas eksperimen dapat dilihat bahwa pada kelas eksperimen terdapat korelasi yang signifikan antara keterampilan berpikir rasional dengan hasil belajar ranah kognitif. Sedangkan pada kelas kontrol tidak terdapat hubungan antara keterampilan berpikir rasional dengan hasil belajar ranah kognitif siswa.

Pada kelas eksperimen keterampilan berpikir rasional tinggi membuat hasil belajar ranah kognitif juga tinggi. Hal ini sejalan dengan pendapat Suparno (2001) secara rasional siswa dapat menganalisis apa-apa yang diamati dan diselesaikan secara benar dan berpikir rasional dapat meningkatkan hasil belajar siswa. Selanjutnya dilihat dari nilai koefisien korelasi ( $\mathrm{r}$ ) dan koefisien determinasi $\left(\mathrm{R}^{2}\right)$ didapat nilai $r$ sebesar 0,361 serta $R^{2}$ sebesar 0,131 . Artinya 13,1\% hasil belajar ranah kognitif dipengaruhi oleh 
keterampilan berpikir rasional, sisanya $86,9 \%$ dipengaruhi oleh faktor lain. Faktor lain yang turut mempengaruhi hasil belajar ranah kognitif bisa saja minat, motivasi belajar siswa, kemampuan guru dalam menyampaikan konsep dan sebagainya. Berdasarkan nilai persamaan regresi antara hasil belajar ranah kognitif awal yang dimiliki siswa adalah sebesar konstanta persamaan regresi yaitu 8,681. Hasil balajar ranah kognitif akan meningkat seiring dengan meningkatnya keterampilan berpikir rasional siswa.

Adanya hubungan antara hasil belajar ranah kognitif dengan keterampilan berpikir rasional menggunakan proses pembelajaran kooperatif disertai dengan pemberian constructive feedback ini juga sesuai dengan penelitian Rahmi (2013) mengenai peningkatan hasil belajar ranah kognitif siswa menggunakan pembelajaran kooperatif dengan pemberian constructive feedback. Dalam penelitian tersebut dijelaskan dengan pemberian constructive feedback pada proses belajar kooperatif, siswa dapat mengetahui dimana letak kesalahan mereka dalam mengerjakan tugas, saling tukar pikiran dengan temannya dalam diskusi, melakukan eksperimen dan saling membantu dalam menyelesaikan masalah, sehingga hasil belajar siswa pada ranah kognitif meningkat dari sebelumnya.

Begitu juga dengan hasil penelitian Rahmi (2014) pemberian constructive feedback pada proses pembelajaran kooperatif dapat meningkatkan keterampilan berpikir rasional siswa. Pada proses pembelajaran kooperatif dengan pemberian constructive feedback diberi pertanyaan-pertanyaan yang menuntut siswa untuk menjawab secara rasional. Didukung dengan adanya praktikum mengenai konsep, sehingga siswa benarbenar melihat fenomena yang terjadi dan menghubungkannya dengan teori

Pada kelas kontrol, tidak terdapat hubungan antara keterampilan berpikir rasional siswa dengan hasil belajar ranah kognitif. Ini mungkin dipengaruhi dengan kondisi belajar dan guru kurang melatihkan lebih mendalam keterampilan berpikir rasional siswa dan hasil belajar ranah kognitif dibandingkan dengan kelas eksperimen. Adapun dilihat dari nilai koefisien korelasi (r) dan koefisien determinasi $\left(\mathrm{R}^{2}\right)$, terlihat nilai $\mathrm{r}$ sebesar 0,214 dan nilai $\mathbf{R}^{2}$ sebesar 0,046 . Artinya hanya $4 \%$ hasil belajar ranah kognitif dipengaruhi oleh keterampilan berpikir rasional.

\section{SIMPULAN}

Berdasarkan analisis hasil penelitian terdapat hubungan antara peningkatan hasil belajar dengan keterampilan berpikir rasional pada kelas eksperimen. Besarnya peningkatan hasil belajar yaitu 0,551dari besarnya nilai keterampilan berpikir rasional. Sedangkan pada kelas kontrol tidak terdapat hubungan antara keterampilan berpikir rasional dengan hasil belajar.

\section{DAFTAR PUSTAKA}

Anderson, L.W., \& Krathwohl, D.R. (2011). Kerangka Landasan untuk Pembelajaran, Pengajaran da Assesmen: Revisi Taksonomi Pendidikan Bloom. Yogyakarta: Pustaka Pelajar

Arikunto, S. (2006). Dasar-Dasar Evaluasi Pendidikan. Jakarta: Bumi Aksara.

Baskoro, Y. (2001).Analisis Keterampilan Berpikir Rasional Siswa SMU Kelas XII Pada Bahan Kajian Kesetimbangan Kimia. Skripsi FMIPA UPI Bandung: tidak diterbitkan

Bhattarai, M.D. (2007). ABCDEFG ISThe Principle of Constructive Feedback. Nepal: Medical Education Unit,NAMS. (http://www.docstoc.com/docs/21 089032/ABCDEFG-IS- 
$\%$ E2\%80\%93-The-Principle-of-

Constructive-Feedback). Diakses tanggal 01 Agustus 2010.

Fraenkel, J. R. dan Wallen, N. E. (2007). How to Design and Evaluate Research in Education (seventh ed.). Singapura: McGraw-Hill Book Co.

Hattie J. \& Timperley H. (2007). "The Power of Feedback" Review of Educational Research. 77, 81-112

Hake, R.R. (1998). InteractiveEngagement versus Tradisional Methods: A Six Thousand-Student Survey of Mechanics Test data for Introductary Physics Courses. American Journal of Physisc, 66(1), pp. 64-74.

Ismienar, S., Andriati, H., dan Vidia, S. (2009). Thinking [Online]. Tersedia: http://psikologi.or.id (20 Juli 2012)

Joyce, B \& Weil, M. with Calhoun, E (1980). Models of Teaching $6^{\text {th }}$ edition. Boston: Allyn and Bacon

Lie, Anita. (2007). Cooperative Learning(mempraktikkan cooperative learning diruangruang kelas). Jakarta: Grasindo

Novak, J.D. (1979). Meaningful Receptional Learning as A Basis for Ratioonal Thingking In Lawson, A.(ed). 1980 AETS yearbook The Psychology of Teaching for Thinking and Creavity. Ohio : Clearing House for science, Mathematics and Environmental Education

Rahmi Zulva (2013). Pembelajaran Kooperatif dengan Pemberian Constructive Feedback Untuk meningkatkan Hasil Belajar Ranah Kognitif Siswa. Jurnal Penelitian Pendidikan, Edisi Khusus Desember 2013, pp. 140145

Rahmi Zulva (2014). Pembelajaran Kooperatif dengan Pemberian
Constructive Feedback Untuk Meningkatkan Keterampilan Berpikir Rasional Siswa SMA. Prosiding Seminar Nasional Pendidikan MIPA 2014 Universitas Negeri Padang, pp. 218-221.

Slavin, Robert E. (2009).Cooperative Learning Teori, Riset dan Praktek. Bandung: Nusa Media

Suparno. P. (2001). Teori Pengembangan Kognitif Jean Piaget. Kanisius: Yogyakarta.

Trianto. (2007). Model-model Pembelajaran Inovatif Berorientasi Konstruktivistik. Jakarta: Prestasi Pustaka.

Wibowo, A. M. (2012). Peningkatan pemahaman konsep sains di madrasah ibtidaiyah melalui perbaikan bahan ajar. Jurnal pendidikan dan pembelajaran dasar: Madrasah. 